\title{
BLENDING ISLAMIC MICROFINANCE AND PRODUCTIVE ZAKAT TO SUPPORT SDGS IN FISHERIES SECTOR
}

\author{
Kevin Joan \\ Faculty of Economics and Business, University of Lampung \\ Email: kevinjoan9@gmail.com \\ Bambang Catur Pambudi \\ Faculty of Economics and Business, University of Lampung \\ Email: bambangcatur10@gmail.com \\ Dimas Putra Adjie \\ Faculty of Economics and Business, University of Lampung \\ Email: dimasputraadzie5454@gmail.com
}

\begin{abstract}
This paper attempts to offer a viable alternative model to tackle credit distribution problems by using integration of the credit distribution strategy between the financial institutions and amil zakat institution based on kafalah contract. The extant literature on the (i) financing constraints faced by fishermen, and (ii) quadruple helix strategy have been reviewed critically and used in the attempt of proposing an alternative model. The paper has developed blending strategy of Islamic microfinance and productive zakat as a source of financing for fishermen in coastal areas. This model is expected to provide fishermen to meet their liquidity constraint in developing their business. The paper is based on conceptual explorations of literature in the area of Islamic microfinance and zakat. This is a conceptual paper, so it did not employ any empirical analysis. The findings of this paper will provide strategy to optimize fishermen's business which will increase their prosperity.
\end{abstract}

Keywords: Productive Zakat, Islamic Microfinance, Kafalah

\section{A. Introduction}

\section{A.1. Background}

Indonesia is one of the countries with the largest number of poor people in Southeast Asia with more than $42 \%$ of Indonesia's population earning less than US \$2 (World Bank, 2005). Based on data from BPS (2018), the number of poverty in Indonesia is high or approximately 25.95 million people. Those numbers are greater than total population of Australia continent. Moreover, the disparity rate between urban and rural area is still quite high with the percentage of poor people in rural areas $(13,20 \%)$ almost doubly the percentage of poor people in urban areas $(7,02 \%)$. According to Zaini (2010), the problem of poverty is inversely proportional with the natural resources in a region. This means, the larger of natural resources in a region, the greater opportunity for community can prosper. Ironically, as the largest archipelago country in the world with abundant potential (Mulyadi, 2005; World Resources, 1998), still faced poverty as a never-ending problem, particularly in coastal areas. 
The amount of poverty in coastal areas reached $32.14 \%$ of the total poverty that occurred in Indonesia (BPS, 2018). Furthermore, 83\% of fishermen still live below the poverty trap (Bapennas, 2008). In fact, the potential of Indonesia's marine resources both biological and non-biological has tremendous potential to be optimized (KKP, 2014). Refers to BPS (2018), Indonesia's marine resources spread 3,51 million $\mathrm{km} 2$ sea areas and 2,936 km2 Zone of Economics Exclusive (ZEE) and the continental shelf spreading of fishing areas in Indonesia which reaches a wide area 5.8 million $\mathrm{km} 2$. According to Sembiring (2013), the potential of Indonesia's marine resources reaches 6.18 million tons per year which consisting of various types of Indonesian marineaquatic animals. Unfortunately, this potential has not been utilized optimally. This is confirmed by the marine and fisheries statistical data by KKP (2014) which stated the total potential of the sea and fisheries only reached 225 trillion rupiahs from what should have been able to reach 3,000 trillion rupiahs each year. Moreover, the aquaculture land that has been utilized is only 1.3 million hectares out of 17.3 million hectares of potential aquaculture land.

The marine sector has great potential to reduce the occurrence of poverty in coastal areas. Unfortunately, this great potential has not been optimally utilized. According to Bappenas (2014), the main problem that makes the fisheries sector is not optimal, both capture fisheries and aquaculture, is the lack of venture capital due to complicated banking loans and high interest. Refers to KKP (2014) most fishermen undergo their work independently on a small scale. Furthermore, non-performing loans (NPLs) in the fisheries sector credit are higher than other sectors, which is $2.54 \%$ while banking aggregate NPLs are only 2.16\% (OJK, 2015). Bank lending tends to be limited to the fisheries sector with a total lending of only $0.21 \%$ of the total national bank credit (OJK, 2015). The low investment rate of the total national banking credit to the fisheries sector is caused by many factors, one of the factors that significantly influence the low level of possibility of refunds (Galih, 2011). To overcome bad credit due to the possibility of low returns, banks usually impose minimum requirements for fishermen who want to get credit assistance in the form of collateral. This serves as a way to guarantee that banks continue to receive repayments from loans channeled if customers got rejected (Hafidah, 2013). Nevertheless, collateral is the main obstacle in granting fisheries credit (OJK, 2015) because $83 \%$ fishermen still live below the poverty line (Bapennas, 2008). Bappenas explained that fishermen tend to pay less attention to the environment in the process of aquaculture and fishing. In fact, sensitivity and attention to the environment can affect the amount of catch or aquaculture production. The phenomenon of overfishing, illegal fishing and low quality fish is the implication of the lack of attention of fishermen to the environment. Thus, the obstacles to the development of the fisheries sector in Indonesia are the difficulty of access to formal financial institutions and the lack of attention of fisheries businesses. Therefore, it is necessary to have an appropriate and relevant policy in order to optimize the potential of Indonesian fisheries to reduce poverty in coastal areas. 


\section{B.2. Conceptual Model}

Based on those problems, it is necessary to provide a real solution hence the process of micro-credit distribution with accessible collateral for poor fishermen. The concept that the authors suggest are becoming productive zakat as a sharia microcredit guarantee which given by formal financial authority for poor fishermen to resolve the main obstacles of credit access. Utilization of productive zakat funds is supported by empowerment programs hence productive zakat can be used optimally. Stakeholders are Islamic microfinance institutions (LKMS), amil zakat institutions (LAZ), Zakat Community Development (ZCD), and Business Development Services (BDS).

\section{A.3. Problem Formulation}

Based on the background above, the problems that will be solved by this paper are:

1. What is the potential for zakat in reducing poverty in Indonesia?

2. What is the mechanism for the use of productive zakat as collateral for microIslamic financing for poor fishermen?

3. What are the benefits resulting from the use of productive zakat as collateral for Islamic microfinance for stakeholders?

\section{A.4. Objective}

Based on the background above, the problems that will be solved by this paper are:

1. Knowing the potential of zakat in reducing poverty in Indonesia.

2. Knowing the mechanism of utilizing productive zakat as collateral for microsharia financing for poor fishermen

3. Knowing the benefits generated by the use of productive zakat as collateral for Sharia microfinance for stakeholders.

\section{A.5 Benefits}

This research is expected to help poor fishermen both in the capture fisheries and aquaculture sectors in order to develop their businesses through access to microcredit with guaranteed productive zakat and to empower their abilities and sensitivity to the environment. Furthermore, the government is expected to implement this idea as an effort to optimize the potential of Indonesian fisheries so as to reduce poverty in coastal areas

\section{B. Literature Study}

\section{B.1. Theoretical Basis}

\section{B.1.1. The Urgency of Poverty Alleviation and its Relation to Zakat}

This paper uses the Social-Democracy theory as its theoretical foundation which sees poverty as a structural foundation caused by the imbalance of socioeconomic structures in the fabric of social life (Meyer, 2008). Seeing that inequality in 
the socio-economic structure is the main focus in the Social-Democracy theory, this means that this theory emphasizes the importance of equality as the main condition for reducing poverty.

From an Islamic point of view, poverty is seen as a disaster that endangers the logic of thought, worship, family, and also society. Therefore, special efforts are needed to overcome poverty. Therefore, a Muslim is ordered to give alms (zakat). Even the command of zakat is mentioned 32 times in the Qur'an. This means, Islam puts the problem of poverty as a fundamental problem that requires special efforts to overcome it. Based on Social-Democracy theory and the poverty paradigm in an Islamic perspective, the use of zakat that has been managed institutionally needs to be optimized so that it can have a significant impact on poverty alleviation efforts.

\section{B.1.2. Implementation of Productive Zakat as a Public Financial Instrument}

Distribution of zakat from LAZ to mustahik (recipient of zakat) is generally given directly and tend to be consumptive, both in the form of money and goods. It is intended that mustahik can feel the direct benefits of zakat that has been distributed. However, according to Yaqin (2015) the pattern of direct distribution of zakat with a consumptive nature is a pattern of distribution that is less effective in overcoming the problem of poverty that occurs in Indonesia. This is because when the benefits of zakat that mustahik receive have expired, they return to a difficult initial life where most of the life is in a debt bondage. Therefore, there is a pattern of zakat distribution which is called productive zakat. Raharjo (1999) defines productive zakat as zakat funds given to mustahik to be used as working capital so that it can help mustahik to increase work productivity which in the long run can lift the mustahik economy. Looking at the strategic function of zakat, it can be concluded that zakat is an important element that can be used as the axis of state finance to reduce poverty. In contrast to dynamic taxes, zakat is permanent in accordance with what is conveyed in the Koran, starting from who the recipient of zakat, zakat giver and the percentage of zakat that must be submitted to amil zakat institutions. The distribution of zakat funds needs to pay attention to two important things, namely to stay away from muhdhorotan and benefit-oriented.

\section{B.1.3. The Kafalah Contract and Its Mechanism in Sharia Financing}

According Krismawati (2013) kafalah contract is a contract where kafil (guarantor of financing) provides guarantees for makful bih (in this case for example financing) given makful lahu (channeling financing) to makful anhu (guaranteed). For this guarantee, makful anhu provides ujroh (fee) to the guarantor of financing through makful lahu. In short, the kafalah contract is a contract to transfer responsibility towards someone who is guaranteed by holding on to the responsibility of another person as a guarantor. There are several sharia financing guarantor institutions in Indonesia that implement the kafalah agreement as a financing guarantee contract. One of them is PT. Jamkrindo Syariah. The figure below explains the mechanism of the kafalah contract as the basis for financing collateral. 


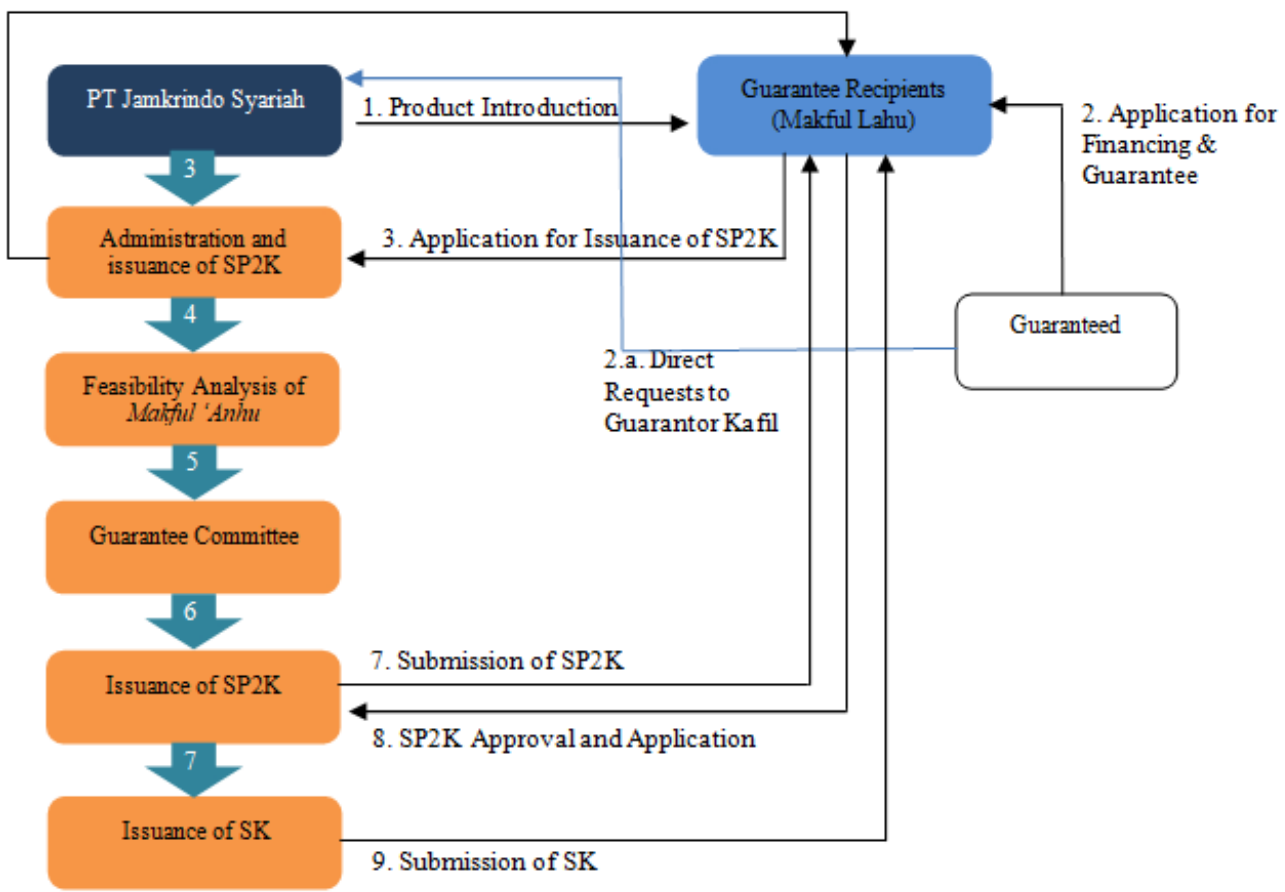

Figure 1. Scheme Agreement Financing Guarantee Scheme by PT Jamkrindo Syariah Source : jamkrindosyariah.co.id

\section{B.2. Previous Research}

Kusumaningrum (2013) states that poverty that occurs in coastal areas is generally caused by factors: 1) Structural, which is more in the technical direction, where the provision of infrastructure facilities to support capture fisheries or cultural fisheries to optimize the potential of Indonesian marine fisheries is still very minimal. The lack of fishermen's facilities and infrastructure is the impact of the lack of funding to fishermen to get adequate infrastructure to optimize the potential of the fisheries sector. 2) Cultural, namely the lack of knowledge, information and skills of fishermen to improve their quality and competitiveness. Moreover, sometimes cultural issues also concern the ethics of fishermen, especially related to the environment. The phenomenon of overfishing, illegal fishing and low quality fish is the implication of the lack of fishermen's attention to the environment. In fact, it is very influential on the catch and the results of aquaculture production. 3) Natural, which is related to nature due to climate and weather disturbances. Policies based on the environment will certainly reduce the impact of climate and weather disturbances. Lubis (2018) explains that easy access to capital and government policies have a positive effect on poverty alleviation. Andriani (2008) states that the ease of access to credit to the amount of credit granted from formal financial institutions to MSM business actors is caused by various factors, one of the most significant factors being collateral. The above studies show that the problem of poverty actually cones on two reasons, namely the difficulty of accessing credit to formal financial institutions and the lack of fishermen's attention to the surrounding 
environment. Difficult access to credit to formal financial institutions is caused by various factors, one of the most significant factors is collateral.

\section{B.3. Research Framework}

This study makes the potential of the fisheries sector and poverty alleviation as the main foundation for the framework of thought. Previous studies have shown a positive relationship between the potential of the Indonesian fisheries sector and poverty alleviation. The role of the fisheries sector in alleviating poverty can be hampered by the difficulty of accessing bank credit due to collateral requirements and the minimum attention of fishermen to the environment. Therefore, it is necessary to have appropriate and relevant strategies and policies to simplify access to bank credit for fishermen, especially poor fishermen, as well as empowering fishermen based on the environment. In formulating the strategies and policies, this study looks at the potential use of productive zakat funds as a solution to guarantee fishery loans to poor fishermen.

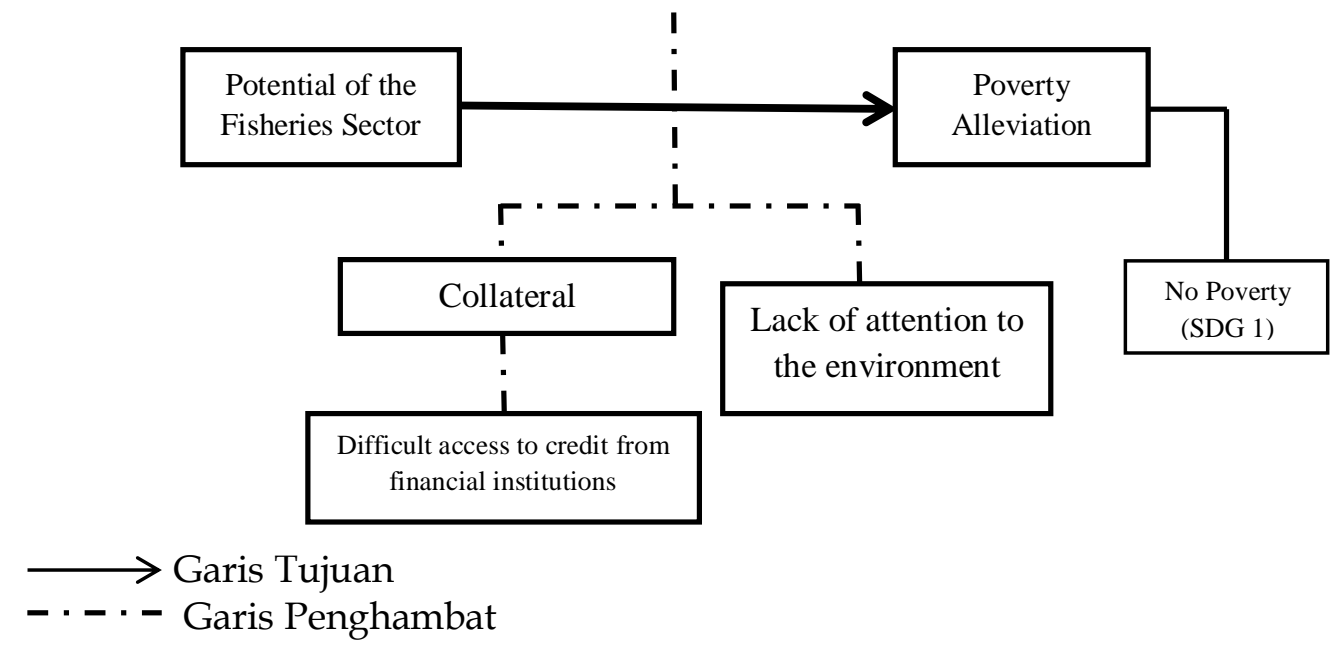

Figure 2. Research Framework

\section{Research Methods}

\section{C.1. Research Methods and Data Collection Techniques}

The method of writing this paper based on literature study. Where data and information obtained from various literature. Then, the data and information obtained are presented descriptively accompanied by analysis of the results of group discussions in order to provide scientific studies that can be further developed.

\section{C.2. Research Coverage}

The aspects to be analyzed are the mechanism of poverty reduction in the fisheries sector through the use of productive zakat combined with sharia microfinance as an innovative model of financial guarantee policy for sharia microcredit. 


\section{C.3. Data Sources and Data Collection Methods}

The information collected is information relating to Islamic microfinance and zakat. The information was obtained from various sources of literature both in the form of data from the Government website, research articles, scientific journals and books that are relevant to the object under study.

\section{C.4. Data Interpretation and Analysis}

The data that has been obtained is then selected to retrieve data relevant to the topic of the problem raised. Then, an analysis is carried out by describing the facts that have been obtained and providing solutions to existing problems from the results of the literature study.

\section{Result And Discussion}

\section{D.1. Zakat Potential as an Instrument for Poverty Alleviation}

Zakat has a huge potential as the axis of state finances in reducing poverty that occurs in Indonesia. Based on BAZNAS (2016), the potential for national zakat in 2015 reached Rp286 trillion. This figure is the result of research using extrapolation methods that consider GDP growth in previous years (Outlook Zakat Indonesia, 2017). The magnitude of the potential of zakat has been realized by the Government, through Bappenas, the government is integrating zakat programs in Zakat Management Organizations (OPZ) into the national program of achieving SDGs (Sustainable Development Goals). The principle of zakat as a tool to tackle poverty is related to SDG number 1, namely no poverty. Meanwhile, the use of zakat is still limited to consumptive zakat which are given for daily needs. Refers to Yaqin (2015), the pattern of distribution of zakat with consumptive zakat is less effective in reducing poverty. Moreover, the pattern of distribution zakat with productive zakat given to the recipients of zakat for long-term income recipients of zakat, is still not optimized by zakat management organizations. According to BAZNAS (2016), productive zakat can have a positive impact on people's welfare and poverty reduction. According to Beik and Pratama (2016), the use of productive zakat funds can increase individual prosperity up to $63.7 \%$.

\section{D.2. Scheme of Utilization Earning Zakat Funds as Guarantee of Sharia Micro Financing Loans for Poor Fishermen Based on Akad Kafalah}

In the Status Quo, government continues to seek credit assistance to fishermen, both capture fisheries and aquaculture. Unfortunately, there are conditions that often prevent fishermen from obtaining credit assistance, namely collateral for loans. Collateral functions as a way to guarantee that the bank still gets repayments from loans given to fishermen even if the fisherman is defaulted. Therefore, the proper strategy is needed hence poor fishermen get credit facilities from the government with an easier mechanism. The author proposed the integration of lending strategies between financial institutions and amil zakat institutions. Zakat can be used as collateral in credit assistance provided by the government to poor fishermen. Credit 
distribution from financial institutions to poor fishermen can be guaranteed by amil zakat institutions. Thus, when poor fishermen cannot pay off their credit debt, zakat funds can be used instead of the credit guarantee. The scheme offered to guarantee credit aimed at fishermen. In particular, poor fishermen (people who do not have assets) and poor people (people whose income is insufficient) because those who are entitled to receive zakat (asnaf) other than destitute and poor are recipients of zakat (mustahik) for zakat (Dahlan, 2003). Furthermore, the mechanism of sharia micro financing for poor fishermen with the use of zakat as a guarantee based on akad kafalah is explained in the following figure.

Financing Guarantee Scheme with Zakat Funds

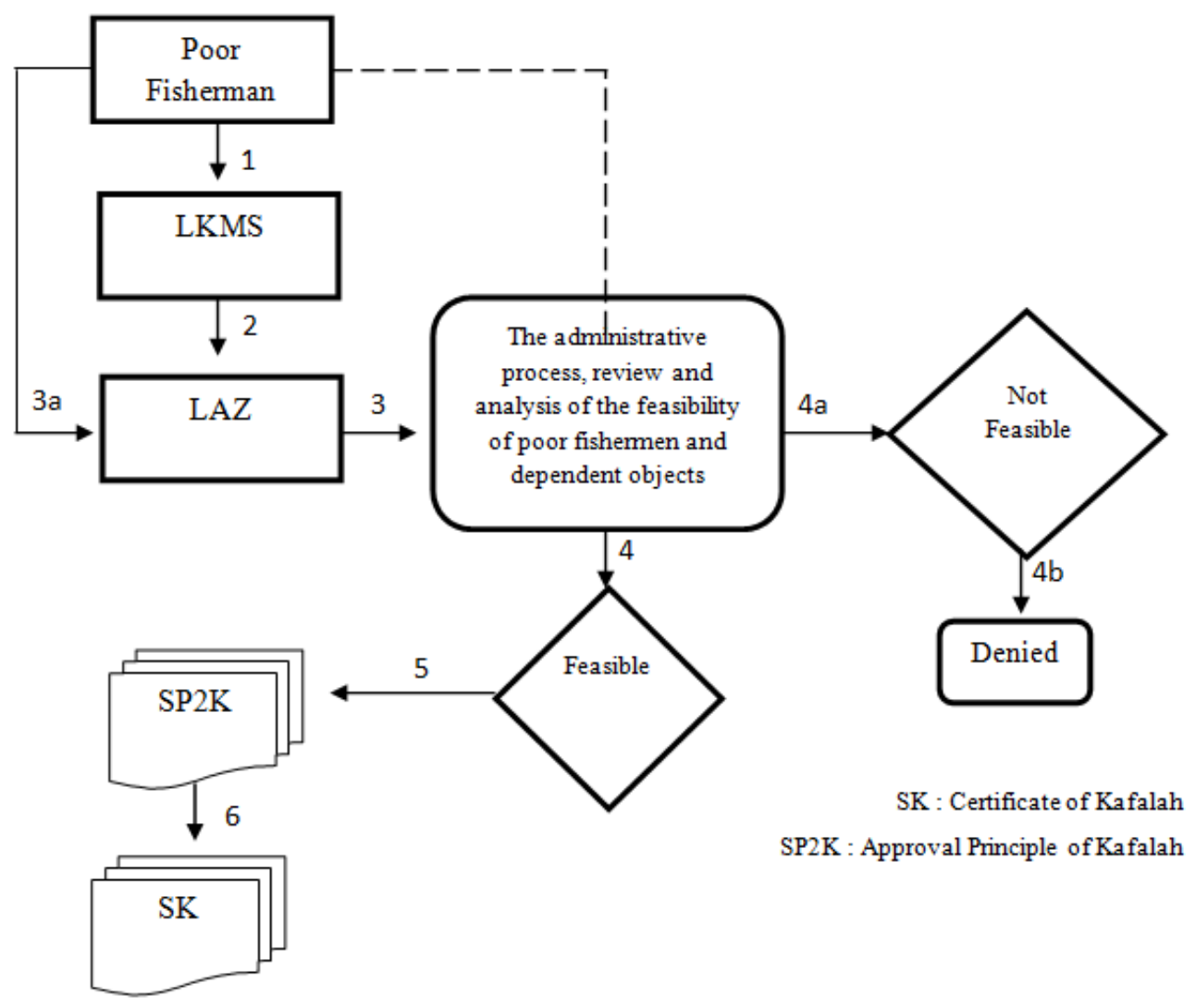

Figure 3. Financing Guarantee Scheme with Zakat Funds

The above scheme is explained as follows:

(1) 1, 2. Fishermen propose financing to LKMS. Then, LKMS confirmed the data of poor fishermen to the Amil Zakat Institute (LAZ).

(2) 3, 3a. If the fisherman is confirmed as a recipient of zakat (mustahik) at LAZ, then the fisherman can carry out the administrative process and LAZ conducts a feasibility review and analysis of the poor fishermen along with the objects proposed by the fisherman in financing. Nonetheless, if the fisherman is not confirmed as the recipient of zakat, the fisherman will need to apply for a 
guarantee in advance to the poor fisherman in order to proceed for the next processes

(3) $4 \mathrm{a}, 4 \mathrm{~b}$. If the analysis result and review conclude that the fisherman is not feasible, then LAZ refuses to provide guarantees to the fishermen because the fishermen are not classified as those who are entitled to receive zakat (ashnaf), especially the poor category.

(4) 4, 5, 6. However, if the analysis result and review conclude that the fisherman is feasible, then LAZ can be issued a Kafalah Principle Approval Letter (SP2K) and Kafalah Certificate (SK) as proof of the financing guarantee agreement.

After the financing guarantee process with zakat funds has been completed, the next step is the process of financing the object requested by poor fishermen with guaranteed zakat funds. More clearly, the following financing schemes with zakat fund guarantees.

Financing Scheme with Guaranteed Zakat Funds

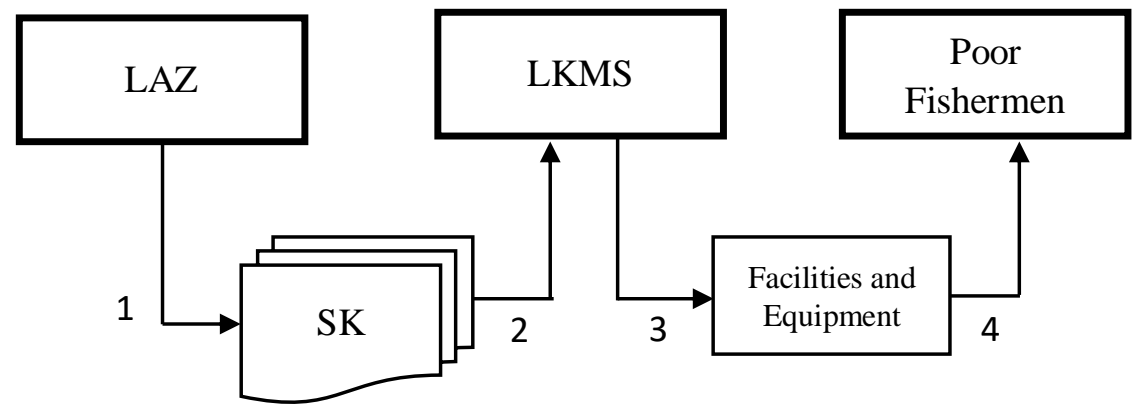

Figure 4. Financing Scheme with Guaranteed Zakat Funds

The above scheme is explained as follows:

(1) 1, 2. After LAZ issued a Kafalah Certificate (SK), LAZ submitted a copy of the decree to LKMS as proof that LAZ was ready to guarantee the financing proposed by poor fishermen.

(2) 3, 4. LKMS finances the object proposed by poor fishermen, the object proposed must have to do with capture fisheries and aquaculture in the form of equipment or equipment.

After the financing process with the guarantee of zakat funds has been completed, the next process is the empowerment and supervision of poor fishermen. More clearly, following the scheme of empowerment and supervision of poor fishermen. 


\section{Poor Fishermen Empowerment and Supervision Scheme}

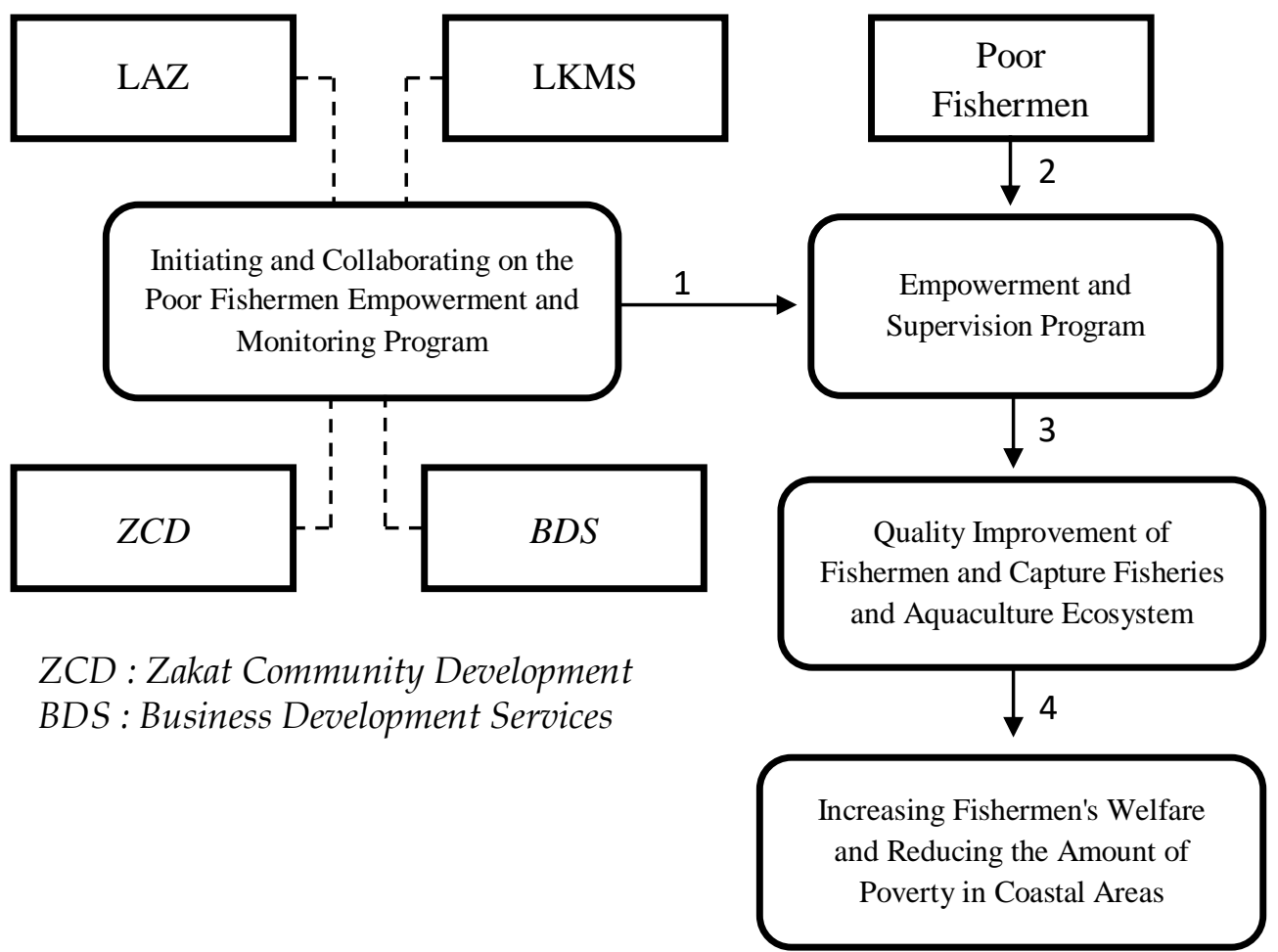

Figure 5. Poor Fishermen Empowerment and Supervision Scheme

The above scheme is explained as follows:

(1) LAZ, LKMS, BDS, and ZCD initiating and collaborating on empowerment and supervision programs for poor fishermen.

(2) The issuance of a kafalah certificate obliges poor fishermen to join the membership of the BDS and ZCD empowerment and supervision program. The empowerment program aims to optimize the work of poor fishermen to be more effective and efficient through training and empowerment using existing equipment or equipment. Empowerment carried out by BDS and ZCD have to pay attention to the environment as the basis of its empowerment. This is done to provide an understanding of the dangers and disadvantages of overfishing, illegal fishing, low quality fish, and other phenomenon. Meanwhile, the supervision program aims to evaluate the performance and supervise poor fishermen to remain responsible for credit settlement even though the credit has been guaranteed by LAZ. Furthermore, the implementation of this strategy has a deadline that adjusts to the specified loan guarantee amount. It is expected that with this deadline the community will be motivated to become zakat providers rather than recipients of zakat.

(3) The existence of credit assistance and empowerment programs will improve the quality of poor fishermen and fisheries ecosystems, both capture fisheries and aquaculture. The increase in quality will impact on the increase in catches and aquaculture production for sale, consumption, and export accompanied by 
healthy, clean and varied fish conditions. Thus, it is more appropriate fishing and cultivation equipment will facilitate fishermen in optimizing their arrest.

(4) When poor fishermen find it easier to optimize their catch and aquaculture. Therefore, it will increase the income of poor fishermen, whose multiplier effect will improve the welfare of fishermen, thereby reducing the amount of poverty in the coastal areas. After the empowerment and supervision process of poor fishermen has been completed, the next process is the payment of installments and repayment of poor fishermen's credit debt to LKMS. More clearly, following the installment payment scheme and credit debt repayment.

\section{Installment Payment and Credit Debt Payment Schemes}

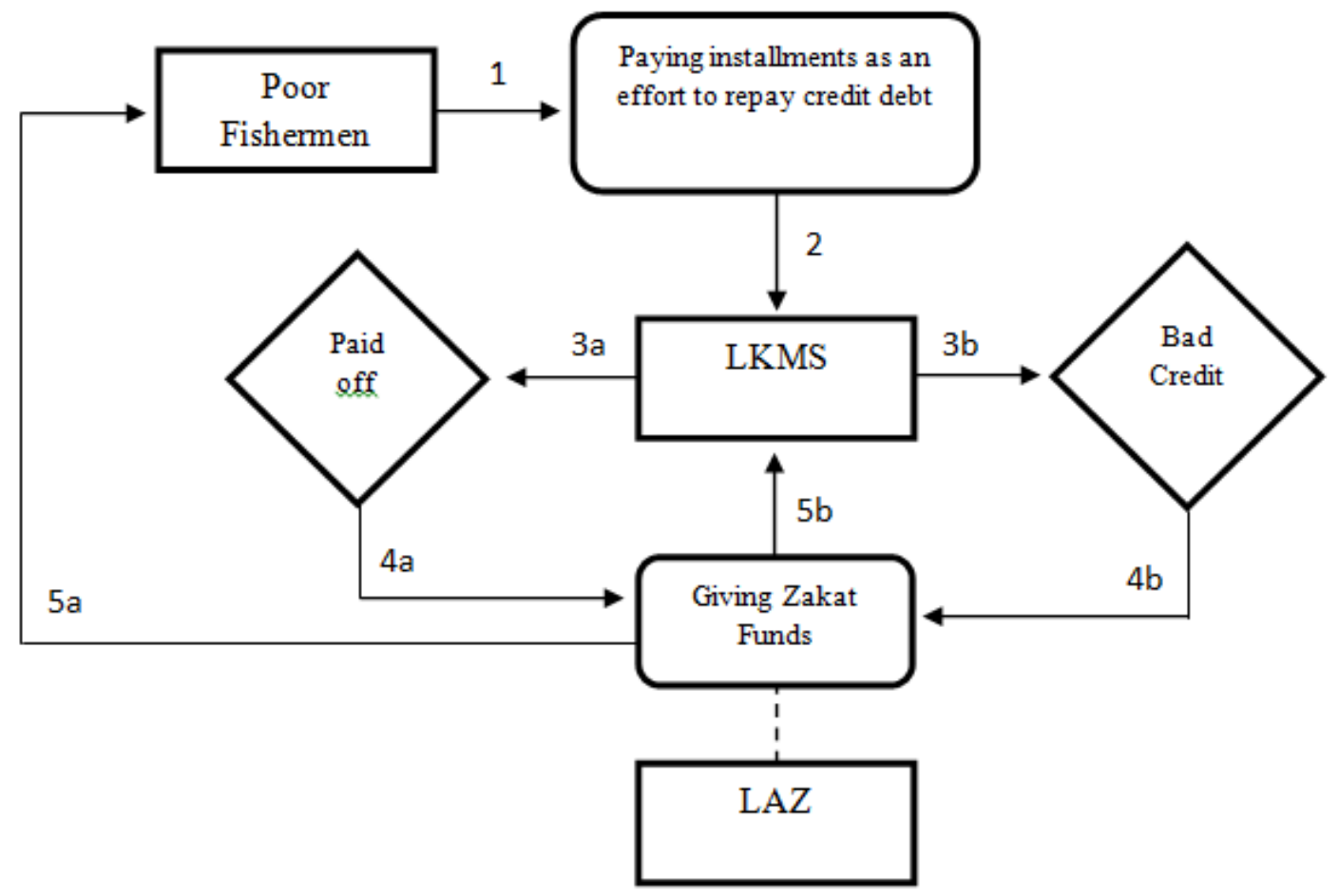

Figure 6. Installment Payment and Credit Debt Payment Schemes

The above scheme is explained as follows:

(1) 1, 2. Poor fishermen pay installments as an effort to repay credit debt to LKMS.

(2) $3 a, 4 a, 5 a$. If the installment payment is paid off and there are no obstacles, then LAZ will provide zakat funds which are used as a guarantee of financing to poor fishermen. This guarantee scheme uses funds that are social in nature, so there is no ujrah (fee) in the guarantee process. Thus, no deductions from zakat are given to poor fishermen if the fishermen pay their installments well. Utilization of this scheme, will make poor fishermen get two assistances such as credit aid from the government channeled through LKMS and zakat funds channeled through LAZ. 
(3) $3 b, 4 b, 5 b$. If the installment payment is not paid off and is experiencing problems or it can be said that bad credit, LAZ will provide zakat funds which are used as collateral for financing to LKMS.

\section{E. Conclusion and Recommendation}

\section{E.1. Conclusion}

To minimize the number of poverty in coastal areas. We need to optimize the potential in fisheries sector. To optimize the potential in fisheries sector, we need to give them credit assistance which helps them increase productivity of their work. But, the problem to get access to credit assistance is credit guarantee. Zakat can be a solution for fishermen to get credit assistance by using productive zakat as a credit guarantee. So that, fishermen can increases productivity of their work which will optimize the potential of fisheries sector. And, surely it will minimize the number of poverty in coastal areas.

\section{E.2 Recommendation}

Solid cooperation among stakeholders is needed to implement this idea successfully as an effort to optimize the potential of the fisheries sector through the use of productive zakat as a loan guarantee on Islamic micro financing to poor fishermen so as to reduce poverty in poor fishermen in Indonesia.

\section{Bibliography}

Abdelbaki, Hisham. 2013. 'The Impact of Zakat on Poverty and Income Inequality in Bahrain' Review of Integrative Business and Economics Research. Vol. 2, No. 1

Ali, A.F.M., Rashid, Z.A., Johari, F.,Aziz, M. 2015. 'The Effectiveness of Zakat in Reducing Poverty Incident: An Analysis in Kelantan, Malaysia'. Asian Social Science. Vol. 11, No. 21

Andriani, Septy. 2018. "Analisis Faktor- faktor yang Memengaruhi Volume Penyaluran Kredit Mikro, Kecil dan Menengah (MKM) di Indonesia" [Skripsi]. Bogor: Institut Pertanian Bogor (IPB)

Azzahid, H., Adawiyah, A.R. 2016. 'Strategi Penggunaan Dana Zakat Sebagai Jaminan Pembiayaan Produktif LKMS'.SECOND Conference.

Badan Pusat Statistik (BPS). 2018. Persentase penduduk miskin Maret 2018 turun menjadi 9,82 persen. https://www.bps.go.id/pressrelease/2018/07/16/1483/persentasependuduk-miskin-maret-2018-turun-menjadi-9-82persen.html@romahurmuziy-mimin (Diakses pada 12 Oktober 2019)

Badan Strategi Nasional. 2014. Rencana Strategis Nasional, http://www.bsn.go.id/ (diakses pada 16 Oktober 2019)

Bappennas. 2008. Penanggulangan Kemiskinan, https://www.bappenas.go.id/files/9213/5229/9772/bab16_20091007161707__17.pdf (Diakses pada 16 Oktober 2019) 
BAZNAS. 2017. Outlook Zakat Indonesia.https://www.puskasbaznas.com/images/outlook/OUTLOOK_ZAKAT_2017 _PUSKASBAZNAS.pdf(Diakses pada 2 Oktober 2019)

Beik, I.S., Pratama C. 2016. 'Zakat Impact on Poverty and Welfare of Mustahik: A CIBEST Model Approach'. AFEBI Islamic Finance and Economic Review. Vol. 01, No. 01.

Bouchikhi, R., Larbi, Ghrissi. 2016.'The Impact of Zakat Fund in Reducing Poverty Case of Algeria'. Mediterranean Journal of Social Sciences. Vol.7, No. 3.

Dahlan, Ahmad. 2010. Pengantar Ekonomi Islam. Purwokerto: STAIN Press.

Dahuri R, Rais J, Sapta P.G., Sitepu M. 2001. Pengelolaan Sumberdaya Wilayah Pesisir dan Lautan Secara terpadu. Jakarta: Saptodadi.

Dahuri, R. 2012. "Aplikasi Blue Economy dalam Pembangunan Kelautan Berkelanjutan", http://rokhmindahuri.info/2012/10/10/1155/ (Diakses pada 14 Oktober 2019)

Deputi Bidang Sumber Daya Alam dan Lingkungan Hidup. 2013. Pembangunan Kelautan dan Perikanan dalam Prioritas Pembangunan Nasional 2015-2019. Kementerian PPN/Bappenas.

Dhompet Duafa Banten. 2017. Disebut 32 Kali dalam Alquran, Ini Penjelasan Wajibnya Zakat bagi Muslim Pilihanhttps://ddbanten.org/disebut-32-kali-dalamalquran-ini-penjelasan-wajibnya-zakat-bagi-muslim-pilihan/

Galih, Tito Adhitya. 2011. Pengaruh Dana Pihak Ketiga, Capital Adequacy Ratio, Non Performing Loan, Return on Assets, dan Loan to Deposit Ratio Terhadap Jumlah Penyaluran Kredit pada Bank di Indonesia. [Skripsi]. Bali: Universitas Udayana

Hafidah, Noor. 2013. "Kajian Prinsip Hukum Jaminan Syariah Dalam Kerangka Sistem Hukum Syariah". Jurnal Rechtidee. Vol. 8. No.2. http://neobis.trunojoyo.ac.id/rechtidee/article/view/696 (Diakses pada 16 Oktober 2019)

Kementerian Kelautan dan Perikanan (KKP). 2012. Statistik Perikanan Tangkap Indonesia.

2014. Statistik Perikanan Tangkap Indonesia.

2017. KKP genjot pemanfaatan potensi budaya laut. http://djpb.kkp.go.id/index.php/arsip/c/492/KKP-GENJOT-

PEMANFAATAN-POTENSI-BUDIDAYA-LAUT/?category_id=9(Diakses pada 13 Oktober 2019)

Krismawati, W., Auliyah, R., dan Rismawati Y. 2013. “Kajian Kafalah pada Koperasi Jasa Keuangan Syariah As-Sakinah di Kamal Bangkalan". Jurnal InFestasi. Vol. 9. Hal 147-160.

Kusumaningrum, Arta. 2013. “Kebijakan Pembangunan dalam Pengentasan Kemiskinan Masyarakat Pesisir (Studi Kasus pada Masyarakat Pesisir di Kabupaten Purworejo, Jawa Tengah)". Jurnal Agriekonomika, ISSN 2301-9948 Vol 2, No 1.

Lubis, Annisa Ilmi Faried. 2018. “Analisis Kualitas Pelayanan, Pembangunan Akses Modal, dan Kebijakan Pemerintah Terhadap Peningkatan Kesejahteraan Nelayan Pesisir di Desa Pahlawan Kecamatan Tanjung Tiram Kabupaten Batubara". Jurnal Ekonomi dan Kebijakan Politik. ISSN : 22527-2772 
Meyer, Thomas. 2008. Demokrasi Sosial dan Libertarian Dua Model yang Bersaing dalam Mengisi Kerangka Demokrasi Liberal. https://library.fes.de/pdffiles/bueros/indonesien/09834.pdf (Diakses pada 13 Oktober 2019)

Mudiastuti, R. D., Nur, T., \& Sudirman, 2014, “Strategi Kebijakan Industri Marine Politan untuk Mendukung Konsep Mamminasata: Model Konseptual dengan Pendekatan Sistem Dinamik", Jurnal Jemis, 2(2), 20-26.

Muhammad, M., Lestari, D., Rosadi, A.Y. 2016. Sharia Microfinance Agency (Shamcy): Meningkatkan Akses Keuangan Masyarakat Dalam Rangka Memberdayakan Ekonomi Umat. SECOND Conference.

Mulyadi, S., 2005, Ekonomi kelautan, Jakarta: PT. Raja Grafindo

Otoriritas Jasa Keuangan (OJK). 2015. Potensi Pertumbuhan Ekonomi ditinjau dari Penyaluran Kredit Perbankan Kepada Sektor Perioritas Ekonomi Pemerintah.https://www.ojk.go.id/id/berita-dankegiatan/publikasi/Documents/Pages/Potensi-Pertumbuhan-Ekonomi-ditinjau-dariPenyaluran-Kredit-Perbankan-Kepada-Sektor-Prioritas/Kajian\%20Kredit\%20\%20Pertumbuhan\%20Eko\%20(final).pdf(diakses pada tanggal 16 Oktober 2019)

Pongtuluran, Yonathan. 2015. Manajemen Sumber Daya Alam dan Lingkungan. https:/ / books.google.com/books?id=V42ACwAAQBAJ\&pg=PA171\&lpg=PA $171 \& d q=$ World + Resources+Institute $+95.181+\mathrm{km} \&$ source $=$ bl\&ots=8yzKEeJXtp \&sig=ACfU3U24rhKeD3AsfEHaMg1LfkkeHvMP7g\&hl=id\&sa=X\&ved=2ahU KEwis_MHTi9_gAhWp8uAKHcyMD4IQ6AEwAHoECAAQAQ\#v=onepage\& q=World \%20Resources\%20Institute\%2095.181\%20km\&f=false (Diakses pada 26 Februari 2019)

PT. Jamkrindo Syariah. 2007. Skema Penjaminan Pembiayaan Berbasis Akad Kafalah oleh PT Jamkrindo Syariah. http://jamkrindosyariah.co.id/mekanisme-ketentuan

Raharjo, M.D. 1999. Islam dan Transformasi Sosial Ekonomi (Jakata: Lembaga Studi Agamadan filsafat.

Sembiring, M. 2013. Ironis Kehidupan Nelayan Miskin ditengah Potensi Perikanan/Kelautan yang Melimpah. http://www.academia.edu/7472834/ (Diakses pada 14 Oktober 2019)

Simorangkir, Eduardo. 2017. Baru 2,6\% Laut Digunakan untuk Budidaya Perikanan RI.https:/ / finance.detik.com/berita-ekonomi-bisnis/d-3451473/baru-26-lautdigunakan-untuk-budidaya-perikanan-ri (Diakses pada 14 Oktober 2019)

Sitorus, Ropesta. 2017. Ini Faktor Penyebab Minimnya Kredit Perbankan ke Perikanan. https:/ / finansial.bisnis.com/read/20170518/90/655125/ini-faktorpenyebab-minimnya-kredit-perbankan-ke-perikanan (Diakses pada 16 Oktober 2019)

Suheera,M.,Nashri, J., Jamaldeen, A. 2015. 'The Role of Zakat on Poverty Alleviation: An Empirical Study At Nintavur, Sri Lanka'. 2ndFIA International SymposiumSouth Eastern University of Sri Lanka.

Suprapto, H., dan Waskita, D. 2014. Bu Susi, Ini Penyebab Nelayan Tetap Miskin, http:/ / m.vivanews.co.id/news/ (Diakses pada 17 Oktober 2019)

Syahyuti. 2006. 30 Konsep Penting Dalam Pembangunan Pedesaan dan Pertanian, PT. Bina Rena Pariwara, Jakarta 
Tilaar, H.A.R. 1997. Pengembangan Sunber Daya Manusia dalam Era Globalisasi, Visi, Misi, dan Program Aksi Pendidikan dan Pelatihan Menuju 2020. Jakarta: Grasindo.

Triarso, Imam. 2012. 'Potensi dan Peluang Pengembangan Usaha Perikanan Tangkap Di Pantura Jawa Tengah', Indonesian Journal of Fisheries Science and Technology.

Triyanti, Riesti. 2016. Tingkat Kesejahteraan Nelayan Skala Kecil Dengan Pendekatan Penghidupan Berkelanjutan di Kabupaten Indramayu, Pusat Penelitian Sosial Ekonomi Kelautan dan Perikanan.

World Bank. 2005. Indonesia Policy Brief. https://siteresources.worldbank.org/INTINDONESIA/Resources/Publication/2800161106130305439/617331-1110769011447/810296-

1110769073153/reducingpoverty.pdf(Diakses pada 15 Oktober 2019)

World Resource Institue. 1998. Laut Indonesia dalam Krisis Laut. https:// www.greenpeace.org/archiveindonesia/PageFiles/533771/Laut\%20Indonesia\%20dalam\%20Krisis.pdf (Diakses pada 15 Oktober 2019)

Yaqin, Ainol. 2015. Optimalisasi Zakat Produktif dalam Pengentasan Problem Kemiskinan. Jurnal Iqtishodia. Vol. 2. No. 2.

Zaini, Ahmad. 2010. Kemiskinan di Daerah Kaya Sumberdaya Alam, Sebuah Paradoks Pembangunan. Jurnal Borneo Administrator. Vol. 6. No. 1. 